\title{
Osphya brusteli sp. nov. from the Balkan Peninsula (Coleoptera: Melandryidae)
}

Osphya brusteli sp. nov. from the Balkan Peninsula (Coleoptera: Melandryidae). - Acta Mus. Siles. Sci. Natur. 65: 271-277, 2016.

\begin{abstract}
A melandryid beetle, Osphya brusteli sp. nov. from the Balkan Peninsula (Greece and Macedonia) is described and illustrated.
\end{abstract}

Key words: Taxonomy, new species, Coleoptera, Melandryidae, Osphya, West Palaearctic Region, Europe, Greece, Macedonia.

\section{Introduction}

The genus Osphya Illiger, 1807 is known from Holarctic (19 species), Neotropical (3 species) and Oriental (4 species) regions (Csiki 1924; Pic 1927; Van Dyke 1928; Nikitsky \& Pollock 2008, 2010; Konvička 2014). Sixteen species are reported from the Palaearctic region (Pic 1927, Nikitsky \& Pollock 2008, Konvička 2014). Only four species are known from Europe so far - Osphya bipunctata (Fabricius, 1775) distributed all over Europe, O. lehnertae Konvička, 2014 from the Peloponnese Peninsula in Greece, O. vandalitiae (Kraatz 1868) from the Iberian Peninsula, and O. aeneipennis Kriechbaumer, 1848 found in the Alps and in the Pyrenees (Nikitsky \& Pollock 2008, Viñolas et al. 2014). Bionomics of the genus is very little known; Nikitsky (1992) stated that larvae of O. orientalis (Lewis, 1895) live in rotten dead wood, maybe in the soil. Below is given a description of a new species from the Balkan Peninsula, from Greece and Macedonia.

\section{Material and methods}

Body length was measured from the anterior margin of the clypeus to the tips of the elytra. Exact label data are cited for the type material. Authors' remarks and addenda are in square brackets, separate label lines are indicated by vertical bar $(\mid)$, separate labels are indicated by two vertical bars $(\|)$. Information in 'quotation marks' indicates the original spelling in the original description. All type material is glued to card. Abdomen and aedeagus of holotype and four paratypes, abdomen and ovipositor of allotype and two paratypes are mounted on separate glue boards pinned under the respective specimens. Type specimens of Osphya brusteli sp. nov. are labelled with red labels with following text: 'Osphya | brusteli sp. nov. | HOLOTYPUS, ALLOTYPUS [or] PARATYPUS | des. Ondřej Konvička 2016’.

The specimens included in this study are deposited in the following collections:

BMNH - Natural History Museum, London, United Kingdom (Max Barclay);

DPPU - Darren Pollock, private collection, Portales, New Mexico, USA;

EEZC - Eduard Ezer, private collection, Zlín, Czech Republic;

ERVI - Enrico Ruzzier, private collection, Venice, Italy;

HBTF - Hervé Brustel, private collection, Toulouse, France;

HNMH - Hungarian Natural History Museum, Budapest, Hungary (Ottó Merkl);

JVOC - Jiří Vávra, private collection, Ostrava, Czech Republic;

LSPC - Lukáš Sekerka, private collection, Praha, Czech Republic;

MNHN - Muséum National d'Histoire Naturelle, Paris, France (Azadeh Taghavian);

MSSJ - Masahiro Saitô, private collection, Sakai-shi, Japan;

NMEG - Naturkundemuseum Erfurt, Germany (Matthias Hartmann);

NMPC - Národní muzeum, Praha, Czech Republic (Jiří Hájek);

OKZC - Ondřej Konvička, private collection, Zlín, Czech Republic. 


\section{Systematic part}

Osphya brusteli sp. nov. (Figs. 1-3, 7-10, 13, 16)

Type locality: Greece occ. bor., Western Macedonia Province, Florina env., Vérno Mts., 2.5 km east southeast of Pisoderi village, $40^{\circ} 46^{\prime} 26^{\prime \prime} \mathrm{N}, 21^{\circ} 16^{\prime} 6^{\prime \prime} \mathrm{E}, 1553 \mathrm{~m}$ a.s.1.

Type material: Holotype: $\hat{\sigma}$ (OKZC), 'Greece, W Macedonia prov. | Florina env., Vérno Mts. | Pisoderi vill., 29.-30.5.2016 | 4046'26"N, 21 ${ }^{\circ} 16^{\prime} 6^{\prime \prime E ~ \mid ~ l g t . ~ O n d r ̌ e j ~ K o n v i c ̌ k a ~[p r i n t e d] ’ . ~ A l l o t y p e: ~ † ~(O K Z C), ~ s a m e ~ d a t a ~ a s ~}$

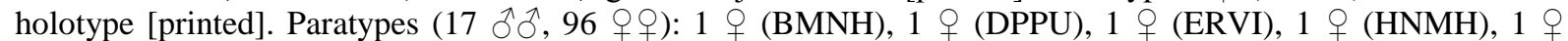

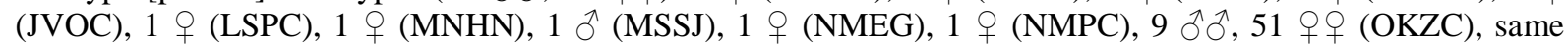

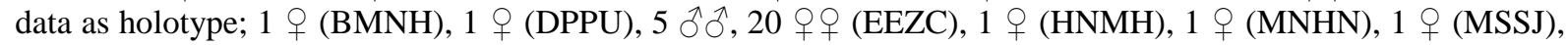
1 o (NMEG), $1 q$ (NMPC), $1 \hat{\jmath}, 1$ (OKZC): 'Greece, W Macedonia prov. | Florina env., Vérno Mts. |

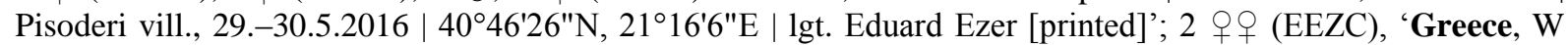
Macedonia prov. | Florina env., Vérno Mts. | Pisoderi vill., 29.-30.5.2016 | 4047'1"N, $21^{\circ} 15^{\prime} 42^{\prime \prime E}$ | lgt. Eduard Ezer [printed]'; 1 ઈ, 3 우 (HBTF), 'Hervé Brustel leg | GR. (FLORINA) | Col de Pisoderi | 12 VI 2007 [printed]'; 1 † (OKZC), 'GREECE occ.b. | Vérno Mts., $1900 \mathrm{~m} \mid$ Pissodéri p. Florina env. [4046'2.85"N, 21 15'14.14"E] | 31.v.2001, subalpin | S. [Stanislav] Benedikt leg. [printed]'; 1 o (NMPC): 'Jugoslavia mer. | Jakupica [Jakupica mountains, Macedonia centr.] 1937 | O.Kodym 12. VI. [printed] || coll. [Josef] Hlisnikovský | P5/720/49 [printed]'; 1 q (NMPC): 'Jugoslavia mer. | Jakupica [Jakupica mountains, Macedonia centr.] 12. VI. | A.Matějka 1937 [printed] || coll. [Josef] Hlisnikovský | P5/720/49 [printed]'; 1 q (NMPC): 'Jakupica, [Jakupica mountains, Macedonia centr.] VI.37 | Jugoslavia mer. | Dr.[Cyrill]Purkyně leg. [printed]'.

\section{Description.}

Male. (Fig. 1) Body length 7.0-12.2 mm (11.2 mm in holotype), width 2.1-3.5 mm (3.2 mm in holotype). Body parallel-sided. Elytra black. Elytra densely pubescent, pubescence long, grey-white to white, darker toward elytral apex. Black pubescence also along sides of elytra (with exception of extreme outer margin, which has grey-white to white pubescence), on humeri, and at base of elytra with exception of suture and inner margin of humeri, which have grey-white to white pubescence. All visible tergites and ventrites mostly black, or particularly black-brown, black-orange or black-brown-orange with long, white pubescence. Tergite V with shorter pubescence, quadrangular with rounded sides and apical margin moderately emarginate, and with two transverse pale spots formed by small, transversely oriented yellowish-white setae. Apex of abdominal ventrite V convex and widely U-shaped (Fig. 10).

Head black. Maxillary palpi yellowish-brown to brown, infuscate towards apices. Labial palpi brown, clypeus yellow. Labrum and mandibles yellowish-brown, in apical parts dark brown to brownish-black. Antennae with 11 antennomeres, first three antennomeres paler coloured (yellow to yellowish-brown). Antennomere IV with base of yellowish-brown and rest dark brown to black. Remaining antennomeres dark brown to black.

Pronotum transverse, convex, and laterally rounded (Fig. 1), black with large yellow to yellow-brown spots in posterior corners, which laterally reach to midlenght of pronotum. These spots of variable size, sometimes their base connected at base of pronotum, exceptionally spots increased in size and reaching to anterior corners. Pronotum shiny, with long greyish-white pubescence and sparsely punctate. Interspaces on disc larger than puncture diameter and gradually narrower towards sides.

Legs black with pro- and mesotibiae in basal fourth and metatibiae in basal $2 / 5-1 / 2$ yellow to yellowish-brown. Apex of metatibiae with one larger and thicker yellow to yellowish-brown spine, and two shorter, acute and thin yellow to yellowish-brown spines. Large spine sometimes reduced, particularly in small males, in which it is only indicated as blunt and black convexity. Trochanters and adjacent bases of femora sometimes yellowishbrown. Metafemora increased in size, particularly in large males.

Aedeagus (Figs 3, 7-9) narrow and long, approximately as long as half of the body length, weakly widening from base to midlength, then conspicuously narrowed apically, narrowest in about 4/5 of length. Apex broad in dorsal view and in larger males elongaterhomboidal. In smaller males angles of rhombus barely indicated to reduced, apex becomes 

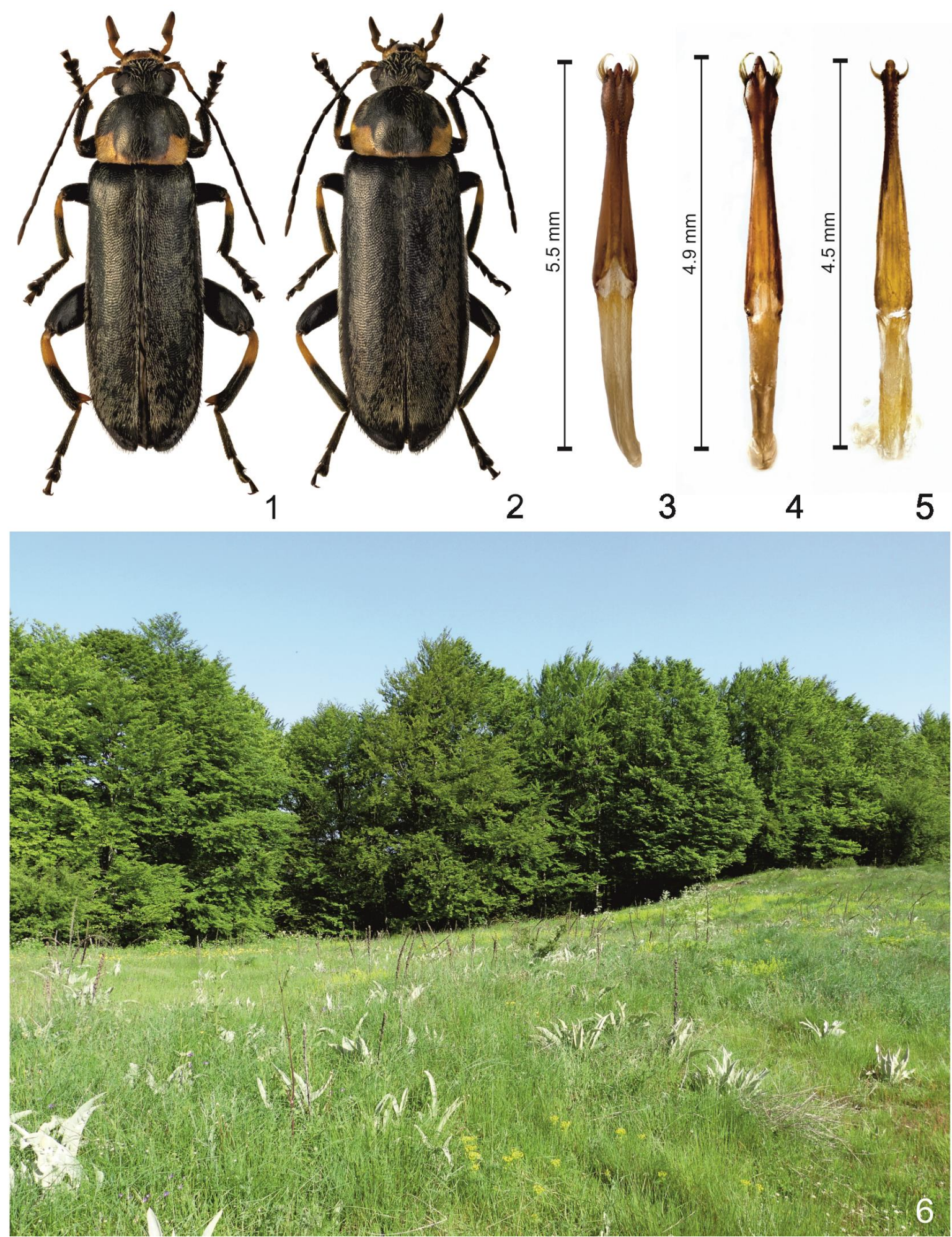

Figs 1-6: 1,3 - holotype male of Osphya brusteli sp. nov.; 2 - allotype female of Osphya brusteli sp. nov.; 4 - holotype male of Osphya lehnertae Konvička, 2014; 5 - male of Osphya bipunctata (Fabricius, 1775); 1 habitus of male in dorsal view; $\mathbf{2}$ - habitus of female in dorsal view; 3, 4, 5 - aedeagus, dorsal view; 6 - the habitat of $O$. brusteli sp. nov. near Pisoderi village. (Figs. 1-5 photo Vlastimil Mihal; Fig. 6 photo Ondřej Konvička). 

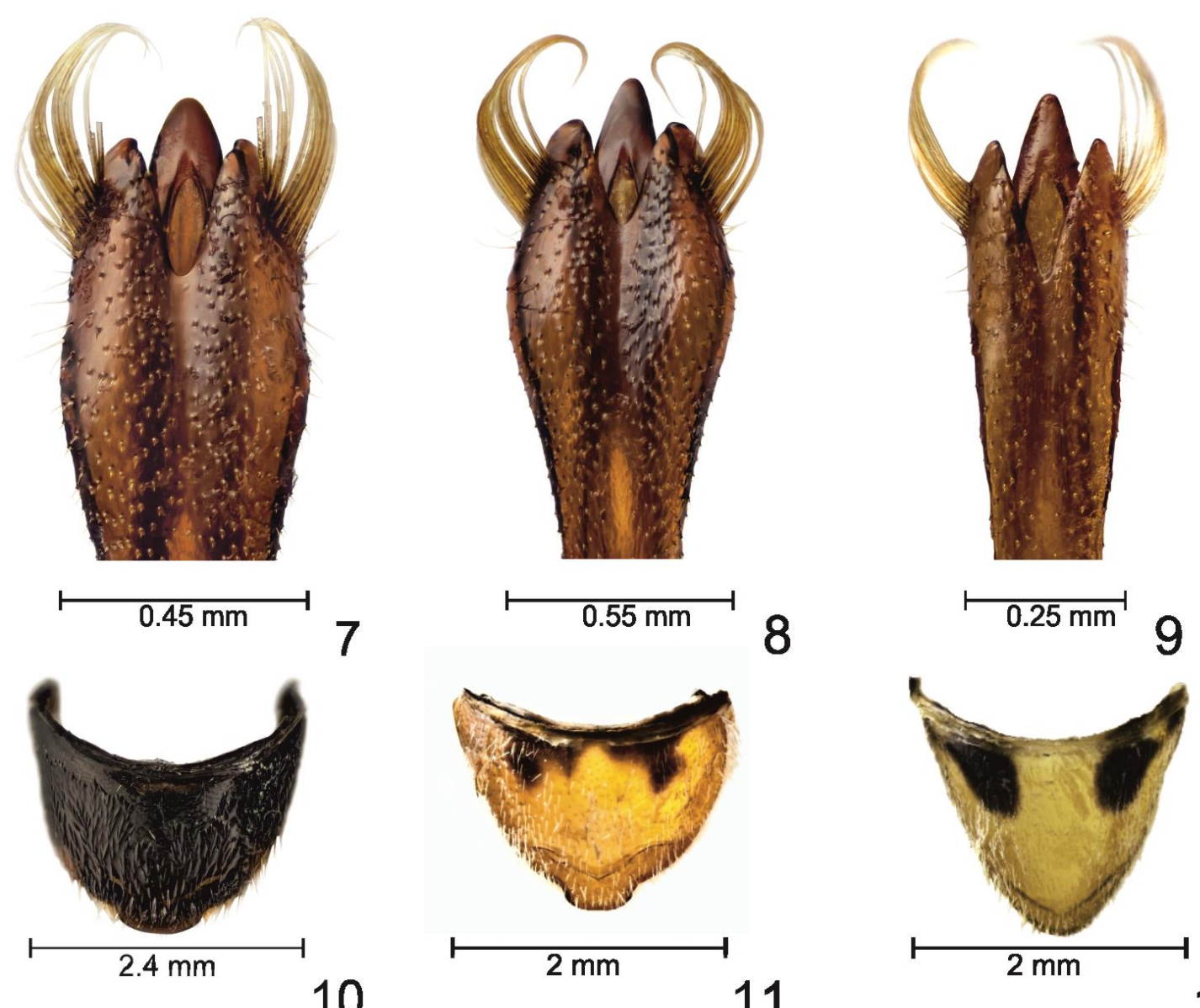

10

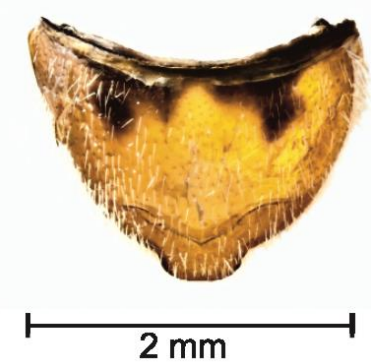

11
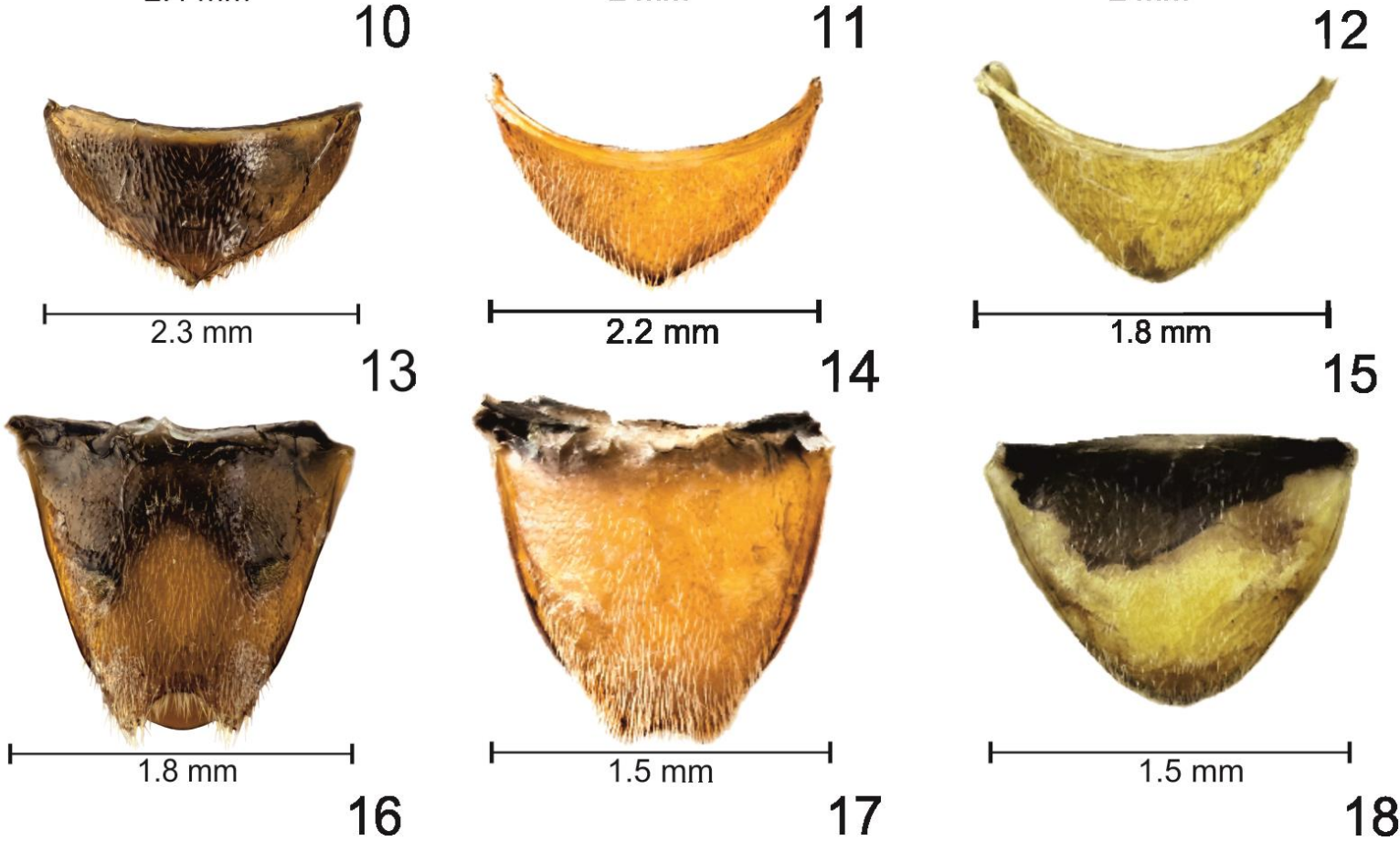

Figs 7-18: 7, 8, 9, 10 - male of Osphya brusteli sp. nov. (7 - holotype); 11 - holotype male of Osphya lehnertae Konvička, 2014; 12 - male of Osphya bipunctata (Fabricius, 1775); 13, 16 - female of O. brusteli sp. nov. (13 allotype); 14, 17 - allotype female of O. lehnertae; 15, 18 - female of $O$. bipunctata; 7, 8, 9 - apex of aedeagus, dorsal view; 10, 11, 12, 13, 14, 15 - the fifth ventrite; 16, 17, 18 - the fifth tergite (Figs. 7-18 - photo Vlastimil Mihal). 
parallel-sided or even slightly dilated on tip. Widest part of aedeagus $1.3-1.6$ times as wide as widest part of apex. Tip of apex regularly and gradually narrowing, narrowly rounded. Dorsal impression on apex shorter than outline of aedeagus.

Female. (Fig. 2) Body length 7.0-13.1 mm (11.4 mm in allotype), width $2.5-4.1 \mathrm{~mm}$ (3.6 mm in allotype). Body more robust and broader than males, broadest in apical half. Colouration as in males, only antennomeres I-III in some specimens darker (mainly antennomere III). Pale spot on pronotum sometimes more or less divided along sides. Tergites and ventrites V-VI orange to brown, sometimes partly black. Metatibiae with two short, acute, narrow, apical spines. Tergite V apically strongly narrowed and more or less emarginate (Fig. 16). Ventrite V pointed and broadly V-shaped (Fig. 13).

Distribution. Greece: Pisoderi; Macedonia: Jakupica Mts.

Bionomy. Unknown.

Collecting circumstances. The adults were found together with several specimens of $O . b i$ punctata on the flowering Apiaceae plants and Cruciata laevipes plants and several adults were collected by sweeping around on a small mountain meadow in beech forest (Fig. 6). One specimen was collected by sweeping on vegetation in the subalpine zone.

Etymology. The species is dedicated to my friend Hervé Brustel (Toulouse, France), very good expert in saproxylic beetles.

Differential diagnosis. Males of $O$. brusteli sp. nov. differs from other species mainly in the shape of aedeagus, the width ratio of the apex and the broadest part of the aedeagus, and the position of dorsal impression on apex. Regarding colouration, body shape, and sexual dimorphism the new species is most similar to O. bipunctata and O. lehnertae. The all three species can be separated by characters given in the Table 1 .

Acknowledgements: I would like to thank Lukáš Sekerka (Praha, Czech Republic) for English translation and comments and corrections to the manuscript; My thanks go also to Josef Jelínek (Praha, Czech Republic) for valuable comments and corrections to the manuscript; Roman Macík (Fryšták, Czech Republic) for help with mounting of figures; Hervé Brustel (Toulouse, France), Eduard Ezer (Zlín, Czech Republic) and Václav Benedikt (Plzeň, Czech Republic) for providing material for study; Kateřina Štajerová (Praha, Czech Republic) for determination of plants; Vlastimil Mihal (Přerov, Czech Republic) for taking photos used in this paper. A special thank is extended to my girlfriend Jana Lehnertová (Zlín, Czech Republic) for her love, patience and general support in the course of my work on the manuscript.

\section{References}

Csiki E. (1924): Serropalpidae. Pp. 1-62. In: Schenkling S. (ed.): Coleopterorum Catalogus. Pars 77. W. Junk, Berlin, 62 pp.

Konvička O. (2014): Osphya lehnertae sp. nov. from Greece (Coleoptera: Melandryidae). - Klapalekiana 50: 161-166.

Nikitsky N.B. (1992): 86. Sem. Melandryidae - Tenelyuby. [86th family Melandryidae - False darkling beetles]. Pp. 435-474. In: Ler P.A. (ed.): Opredelitel' nasekomykh Dal'nego Vostoka SSSR v shesti tomakh. Tom III. Zhestkokrylye, ili zhuki. Chast 2. [Key to the insects of the Far East of the USSR in six volumes. Volume III. Coleoptera. Part 2]. Nauka, Sankt-Peterburg, 704 pp. (in Russian).

Nikitsky N.B. \& Pollock D.A. (2008): Family Melandryidae Leach, 1815. Pp. 64-73. In: Löbl I. \& Smetana A. (eds): Catalogue of Palaearctic Coleoptera, Vol. 5: Tenebrionoidea. Apollo Books, Stenstrup, $670 \mathrm{pp}$.

- (2010): 11.6. Melandryidae Leach, 1815. Pp. 520-533. In: Leschen R.A.B., Beutel R.G. \& Lawrence J.F. (eds): Handbook of Zoology. Arthropoda: Insecta. Coleoptera, Beetles. Morphology and systematics. Volume 2 (Elateroidea, Bostrichiformia, Cucujoidea partim). Walter de Gruyter, Berlin/New York, xiii+786 pp.

Pic M. (1927): Coléoptères de l'Indochine. - Mélanges Exotico-Entomologiques 49: 1-36. 
Van Dyke E.C. (1928): New species of heteromerous Coleoptera. - Bulletin of the Brooklyn Entomological Society 23: 251-261.

Viñolas A., Muños Batet J., Masó G. \& Soler J. (2014): Nuevos registros de coleópteros interesantes del Parque Natural del Cadí-Moixeró, Cataluña (Península Ibérica) (Coleoptera). - Arquivos Entomolóxicos 12: 91-96.

\section{Appendix}

Table 1: Differential diagnosis between $O$. brusteli sp. nov., O. lehnertae Konvička, 2014 and O. bipunctata (Fabricius, 1775).

\begin{tabular}{|c|c|c|c|}
\hline & O. brusteli sp. nov. & O. lehnertae Konvička, 2014 & O. bipunctata (Fabricius, 1775) \\
\hline aedeagus & $\begin{array}{l}\text { apex broad, elongate to } \\
\text { elongate-rhomboidal; } \\
\text { widest part of aedeagus } \\
1.3-1.6 \text { times as wide as } \\
\text { widest part of apex; tip of } \\
\text { apex regularly narrowing; } \\
\text { dorsal impression shorter } \\
\text { than outline of aedeagus } \\
\text { (Figs } 3,7-9 \text { ) }\end{array}$ & $\begin{array}{l}\text { apex broad, elongate- } \\
\text { rhomboidal; widest part of } \\
\text { aedeagus } 1.1 \text { times as wide as } \\
\text { widest part of apex; tip of apex } \\
\text { regularly narrowing; dorsal } \\
\text { impression longer than outline of } \\
\text { aedeagus (Fig. 4) }\end{array}$ & $\begin{array}{l}\text { apex not broad, elongate; widest } \\
\text { part of aedeagus } 1.8-2.2 \text { times as } \\
\text { wide as widest part of apex; tip of } \\
\text { apex parallel-sided and broadly } \\
\text { rounded (Fig. 5) }\end{array}$ \\
\hline $\begin{array}{l}\text { metatibiae in } \\
\text { males }\end{array}$ & $\begin{array}{l}\text { without inner spine in the } \\
\text { middle }\end{array}$ & $\begin{array}{l}\text { with prominent inner spine in the } \\
\text { middle }\end{array}$ & without inner spine in the middle \\
\hline $\begin{array}{l}\text { apex of ventrite } \\
V \text { in males }\end{array}$ & broadly rounded (Fig. 10) & broadly rounded (Fig. 11) & bluntly pointed (Fig. 12) \\
\hline $\begin{array}{l}\text { apex of ventrite } \\
V \text { in females }\end{array}$ & pointed (Fig. 13) & pointed (Fig. 14) & rounded (Fig. 15) \\
\hline $\begin{array}{l}\text { apex of tergite } \mathrm{V} \\
\text { in females }\end{array}$ & emarginate (Fig. 16) & emarginate (Fig. 17) & rounded (Fig. 18) \\
\hline disc of pronotum & $\begin{array}{l}\text { more shiny with sparser } \\
\text { punctuation; interspaces } \\
\text { wider than puncture } \\
\text { diameter }\end{array}$ & $\begin{array}{l}\text { more shiny with sparser } \\
\text { punctuation; interspaces wider } \\
\text { than puncture diameter }\end{array}$ & $\begin{array}{l}\text { less shiny with denser punctuation; } \\
\text { interspaces narrower than puncture } \\
\text { diameter }\end{array}$ \\
\hline $\begin{array}{l}\text { outer margin of } \\
\text { elytra }\end{array}$ & always black & always at least partly yellow & yellow, orange or black \\
\hline
\end{tabular}

\section{Souhrn}

\section{Osphya brusteli sp. nov. z Balkánského poloostrova (Coleoptera: Melandryidae)}

V článku je popsán nový druh Osphya brusteli sp. nov. z čeledi Melandryidae, podčeledi Osphyinae z Makedonie a z Recka. Nalezen byl v centrální Makedonii v pohoří Jakupica a v severozápadním Řecku v pohoří Vérno u obce Pisoderi (typová lokalita). V okolí obce Pisoderi byla imaga nalezena na květech a stoncích miříkovitých rostlin a na květech svízelky chlupaté (Cruciata laevipes) společně s několika kusy druhu Osphya bipunctata (Fabricius, 1775). Naprostá většina jedinců se vyskytovala na malé horské loučce mezi bukovými lesy. Jeden jedinec byl chycen v subalpínském pásmu při smyku vegetace. O. brusteli je zbarvením, tvarem těla a pohlavním dimorfizmem nejvíce podobný druhům O. bipunctata a Osphya lehnertae Konvička, 2014, které se na Balkánském poloostrově taktéž vyskytují. Od nich se samci liší zejména tvarem aedeagu a poměrem šířky apexu a nejširší části aedeagu. Dále se od obou druhů liší tím, že špice aedeagu O. brusteli se rovnoměrně zužuje, na konci je úzce zaoblená a dorzální vtlak ve špici apexu je kratší než základní 
obrys aedeagu. Od $O$. bipunctata se samci liší tvarem pátého ventritu, samice tvarem pátého tergitu a pátého ventritu. Oproti $O$. lehnertae chybí trn na vnitřní straně zadních holení samců a u obou pohlaví není u švu v zadní části krovek př́itomna oranžová skvrna ani její náznak. Zbarvení krovek $O$. brusteli sp. nov. je černé a není variabilní, na rozdíl od velmi barevně variabilního druhu O. bipunctata a od $O$. lehnertae, která má okraje krovek vždy alespoň částečně oranžové. Štít u $O$. brusteli sp. nov. a O. lehnertae je lesklejší, tečkování je řidší než u $O$. bipunctata. Vzdálenost teček na disku u $O$. brusteli sp. nov. a $O$. lehnertae je větší než je průměr teček, kdežto u $O$. bipunctata jsou mezery mezi tečkami menší než jejich průměr. Velikost skvrny na štítu $O$. brusteli sp. nov. je variabilní.

Author's address: Ondřej Konvička, Kúty 1959, CZ-760 01 Zlín, Czech Republic \& Institute of Entomology, Biology Centre AS CR, Branišovská 31, CZ-370 05 České Budějovice, Czech Republic.

E-mail: brouk.vsetin@centrum.cz 